\title{
MODELS OF HETEROGENEOUS AGENTS' BEHAVIOR IN A CONFLICT AND THEIR IMPLEMENTATION ALGORITHMS
}

\author{
N.Yu. Mutovkina ${ }^{1}$,Ph.D. (Engineering), Associate Professor, letter-boxnm@ya.ru; \\ A.Yu. Klyushin 1 ,Ph.D. (Engineering), Associate Professor, klalex@inbox.ru; \\ N.A. Semenov1, Dr.Sc. (Engineering), Professor, is@tstu.tver.ru
}

${ }^{1}$ Tver State Technical University, Nikitin Quay 22, Tver, 170026, Russian Federation

\begin{abstract}
The article discusses pair models of agents' behavior in a conflict. Each agent has one of three possible behavioral types: deviating, compromise and coercing. A behavioral type determines an agent's nature and specifies agent's reaction that should be expected in response to specific actions. The authors select the need to share limited resources as the main cause of a conflict in simulation. The agents need resources to implement assigned tasks and to exist themselves. It is determined that in a conflict situation each agent tries to obtain more resources, than its opponent at the moment. The value of this commitment depends on an agent's behavioral type. The article identifies the technique of selecting the best behavioral model. It also proposes the measures to resolve conflict between agents. The authors applied the basic concepts of fuzzy logic in simulation.

Keywords: conflict between agents, behavioral type, fuzzy logic, behavioral model, level of resource availability.
\end{abstract}

The authors have already discussed the problem of interaction between agents in a multi-agent system (MAS) in [1-3]. They have also considered the models of agents' goal-seeking behavior and analyzed the impact of these models on system stability. The value of agents' winning depends on the behavior model which is chosen by an agent. Special attention is paid to the interaction model of agents in conflict. The conflict between agents is interpreted as a contest in which agents seek to achieve mutually exclusive statuses; each of them wants something that only one of them can receive [1]. The main causes of conflicts are: limited shared resources that agents have to share among themselves; the differences of agents' interests, goals and beliefs, behavioral patterns caused by behavioral types [4]; differences in the number and complexity of tasks assigned to agents. At the same time each agent owns a certain behavioral type $r, r \in R$, that reflects agent's preferences. A behavioral type is a value of an agent's state when performing a specific task; $R$ is a set of possible preferences of an agent. In [5] the authors introduced the following semantic rules: the agent is deviating if $r \in(0,0,5)$; the agent is called compromise (collaborating) if $r \in[0,5,0,8]$ and the agent is coercive if $r \in(0,8,1)$. According to the results of the study, compromise agents are ready to make concessions when sharing resources and tend to avoid conflict situations. Coercing agents usually seek to capture as many resources from other agents as possible. Deviating agents are characterized by the fact that the agent relies only on himself and prefers avoiding any interactions with other agents. Nevertheless, conflicts are inevitable when a problem is solved by two or more agents. Typically, the initiators of a conflict are coercing agents, but in some cases the agents of other behavioral types can also trigger a conflict. A conflict situation can arise even when there is only one agent when he starts having some doubts about the correctness of actions and behavior in different operation conditions. Then the subject of research is an intrapersonal conflict [6]. Utopia is the idea of the possibility of achieving an absolutely peaceful state in MAS, when agents interact in harmony with each other and with themselves. As a rule, the efforts for total elimination of conflicts do not lead to a positive result. It should be noted, that in addition to a destructive function conflicts can have a positive impact: different points of view are identified, we may receive additional information, etc. [7]. So the focus should be on the control and management of conflicts in MAS

\section{Problem statement}

When constructing a behavioral model of two agents in a conflict, the authors took into account the following considerations:

- each agent in MAS is seeking to increase his resource potential within his capabilities, even if he is not a rival for other agents. This desire is dictated by the logic: no resources no life;

- a conflict can occur between agents of the same behavioral type, as well as between agents of different types;

- each agent in the conflict will seek to increase his resources depending on the resources of other agent;

- the rates of increasing resources constrain the limitation of their total number, costs of available resources for new resources (the costs to support agent's activity) and "fatigue" of agents due to the struggle for resources;

- environment may affect the change of agent's resource potential regardless its behavioral type. For example, some agents may share their resources with this agent, while others, on the contrary, take aggressive actions.

A agents' behaviorial model in conflict situations is a dynamic model with a discrete time $t, t=\overline{0, T}$, where 
$T$ is a completion moment of resource distribution.

Simulation uses the following notations:

- $R_{t}^{i}, R_{t}^{j}$ are resource availability levels of agents $i$ and $j$ in moment of time $t, 0 \leq R_{t}^{i}, R_{t}^{j}<1$ respectively;

- $\eta_{t}^{i}, \eta_{t}^{j}$ are reaction coefficients of the agents $i$ and $j$ on the acquisition of part of resources by an opponent $0<\eta_{t}^{i}<R_{t}^{i}, 0<\eta_{t}^{j}<R_{t}^{j}$ respectively;

- $\lambda_{t}^{i}, \lambda_{t}^{j}$ are the coefficients expressing "fatigue" of relevant agents from the struggle for resources in conflict, $0<\lambda_{t}^{i}<R_{t-1}^{i}, 0<\lambda_{t}^{j}<R_{t-1}^{j}$;

- $\chi_{t}^{i}, \chi_{t}^{j}$ are the coefficients expressing that agents realize the needed in resources, a level of "maturity instinct" in resource potential capacity, $0<\chi_{t}^{i}, \chi_{t}^{j}<1$;

- $\varepsilon_{t}^{i}, \varepsilon_{t}^{j}$ are random components that are associated with environmental influence on agents' activities, $-1<\varepsilon_{t}^{i}, \varepsilon_{t}^{j}<1$. The closer their values to $(-1)$, the more hostile the environment. Positive values indicate the benevolence of the environment. A zero value indicates a neutral environment.

$R_{t}^{\text {total }}$ is a total volume of resources in the system at the moment of time $t$ determined by the formula:

$$
\begin{aligned}
& R_{t}^{\text {total }}=R_{t-1}^{\text {total }}-\left(R_{t-1}^{i}+R_{t-1}^{j}\right), \\
& t=\overline{0, T}, R_{0}^{\text {total }}=1 .
\end{aligned}
$$

Thus, the model of the behavior of two agents in a conflict can be represented as:

$$
\begin{aligned}
& \left\{\begin{array}{l}
R_{t+1}^{i}=\eta_{t+1}^{i} \cdot R_{t}^{j}-\lambda_{t+1}^{i} \cdot R_{t}^{i}+\chi_{t+1}^{i} \cdot R_{t}^{\text {total }}+\varepsilon_{t+1}^{i}, \\
R_{t+1}^{j}=\eta_{t+1}^{j} \cdot R_{t}^{i}-\lambda_{t+1}^{j} \cdot R_{t}^{j}+\chi_{t+1}^{j} \cdot R_{t}^{\text {total }}+\varepsilon_{t+1}^{j},
\end{array}\right. \\
& t=\overline{0, T} .
\end{aligned}
$$

Values $\eta_{t}^{i}, \eta_{t}^{j}, \lambda_{t}^{i}, \lambda_{t}^{j}, \chi_{t}^{i}, \chi_{t}^{j}$ depend on the behavioral type agents and are calculated:

$$
\left\{\begin{array}{l}
\eta_{t+1}^{i}=\frac{\left[k_{1}\left(r_{i}\right)\right] \cdot\left(R_{t}^{j} / R_{t}^{i}\right)}{100}, \\
\eta_{t+1}^{j}=\frac{\left[k_{1}\left(r_{j}\right)\right] \cdot\left(R_{t}^{i} / R_{t}^{j}\right)}{100},
\end{array}\right.
$$

where $k_{1}\left(r_{i}\right), k_{1}\left(r_{j}\right)$ are constants that are determined by a psycho-behavioral type of a corresponding agent. They show the agent's desire to join the fight for the right to possess resources;

$$
\left\{\begin{array}{l}
\lambda_{t+1}^{i}=\left[k_{2}\left(r_{i}\right)\right] \cdot R_{t}^{i}, \\
\lambda_{t+1}^{j}=\left[k_{2}\left(r_{j}\right)\right] \cdot R_{t}^{j},
\end{array}\right.
$$

where $k_{2}\left(r_{i}\right), k_{2}\left(r_{j}\right)$ are constants which depend on a type of an agent. It is determined empirically that agents prone to evasion and competition (aggression) spend more energy than compromise agents since the latter receive additional energy from positive emotions that arise from resolving a conflict through compromise [8]. Such agent will always receive at least a part of a planned winning, but it's better than nothing.

$$
\left\{\begin{array}{l}
\chi_{t+1}^{i}=1-\left|\left(R_{t}^{\text {total }}-\left(R_{t}^{i}+R_{t}^{j}\right)\right)\right|^{k_{3}\left(r_{i}\right)}, \\
\chi_{t+1}^{j}=1-\left|\left(R_{t}^{\text {total }}-\left(R_{t}^{i}+R_{t}^{j}\right)\right)\right|^{k_{3}\left(r_{j}\right)},
\end{array}\right.
$$

where $k_{3}\left(r_{i}\right), k_{3}\left(r_{j}\right)$ are constants calculated as an average agent type (or average condition), i.e. $k_{3}\left(r_{i}\right)=\bar{r}_{i}$, $k_{3}\left(r_{j}\right)=\bar{r}_{j}$.

The resource allocation process ends with the following situation:

$$
R_{t+1}^{i}+R_{t+1}^{j} \geq R_{t}^{\text {total }} \text {. }
$$

The task is to analyze six pairwise interaction models of agents in a conflict. It is necessary for obtaining answers to the following questions:

- how much the resource distribution depends on a psycho-behavioral type of an agent and when the distribution is faster;

- how allocation of resources changes depending on a resource volume at the initial stage;

- what are resource allocation rates when reducing the overall level of resources $R_{t}^{\text {total }}$;

- which interaction model is the most optimal for given initial conditions, i.e. allows allocating the resource $R^{\text {total }}$ fully in a reasonable time?

\section{The simulation algorithm}

Construction of behavioral models of heterogeneous agents in a conflict includes several stages:

- analysis of psycho-behavioral types of interacting agents and determining the values of the coefficients $k_{1}\left(r_{i}\right), k_{1}\left(r_{j}\right), k_{2}\left(r_{i}\right), k_{2}\left(r_{j}\right), k_{3}\left(r_{i}\right), k_{3}\left(r_{j}\right)$. It is shown in table 1 ;

- determining the values $R_{0}^{i}, R_{0}^{j}, R_{0}^{\text {total }}, \varepsilon_{0}^{i}$ and $\varepsilon_{0}^{j}$

- calculating the values $\eta_{t+1}^{i}, \eta_{t+1}^{j}, \lambda_{t+1}^{i}, \lambda_{t+1}^{j}$, $\chi_{t+1}^{i}, \chi_{t+1}^{j}$ when $t=\overline{0, T}$ using the formulas (3)-(5);

- calculating the values $R_{t+1}^{i}, R_{t+1}^{j}$ using formulas (2) and defining the balance of resources $R_{t}^{\text {total }}$ by the formula (1);

- testing the condition (6); if it is fulfilled, the process stops;

- calculating a cumulative summary of the distribution by the formulas:

$$
\begin{aligned}
& \operatorname{cumR}_{T}^{i}=\sum_{t=0}^{T} R_{t}^{i}, \operatorname{cumR}_{T}^{j}=\sum_{t=0}^{T} R_{t}^{j}, \\
& \operatorname{cumR}_{T}^{\text {total }}=\operatorname{cumR}_{T}^{i}+\operatorname{cum}_{T}^{j} ;
\end{aligned}
$$

- forming the final tables - table 2 and table 3;

- conclusions and suggestions based on the simulation results; 
- numerical experiments with changing source data;

- analysis of the results of the experiments and general conclusions.

Modeling is possible in any software environment that supports drawing up charts and graphs and allows performing mathematical calculations. The authors have chosen MS Excel 2013 for its simplicity and clarity.

\section{Demo}

According to the abovementioned algorithm, we have determined the following values of the coefficients $k_{1}\left(r_{i}\right), k_{1}\left(r_{j}\right), k_{2}\left(r_{i}\right), k_{2}\left(r_{j}\right), k_{3}\left(r_{i}\right), k_{3}\left(r_{j}\right)$ for the listed psycho-behavioral types of agents.

The values of the constants that depend on a psycho-behavioral type of an agent

\begin{tabular}{|l|c|c|c|}
\hline \multirow{2}{*}{\multicolumn{1}{c|}{ Agent type }} & \multicolumn{3}{|c|}{ Constants } \\
\cline { 2 - 4 } & $k_{1}$ & $k_{2}$ & $k_{3}$ \\
\hline Deviating & 1,0 & 0,50 & 0,25 \\
\hline Compromise & 1,0 & 0,35 & 0,65 \\
\hline Coercing & 1,5 & 0,50 & 0,90 \\
\hline
\end{tabular}

Let $T=5, R_{0}^{\text {total }}=1, R_{0}^{i}=0,01, R_{0}^{j}=0,01, \varepsilon_{0}^{i}=0$ and $\varepsilon_{0}^{j}=0$, i.e.:

- at the zero phase there is $100 \%$ resource that should be distributed in five iterations;

- each agent at the zero stage is assigned to $1 \%$ of resource;

- the influence of external factors is absent, i.e. no one helps agents, but no one interferes with them.

In addition, we consider a situation when the resource is not replenished. It is believed that a given quantity of a resource should be enough for the task.
As a rule, the conflict intensifies in terms of nonrenewable resources. Therefore, one of the measures allowing minimizing a conflict between agents is the replenishment of resources. However, from the economic point of view, such event is not always possible.

Stages 3, 4 and 6 of the algorithm involve the formation of calculated tables and graphs with cumulative results (fig. 1 and fig. 2). The highest point on each chart indicates the full allocation of resources with creation of a specific deficit in virtue of the conflict. So at the end of the distribution we may take the previous step.

In figure 1a) illustrates the interaction of deviating agents, in figure $1 \mathrm{~b}$ ) illustrates the interaction of agents of a compromise type and in figure 1c) illustrates the behavior when dividing the resource between coercing type agents.

As it can be seen from figure 1, the behavior of compromise type agents is the most similar to the resource allocation condition. At the fourth iteration, they still have $37 \%$ unallocated resource. When maintaining a conflict at the fifth iteration they have a resource shortage of $26 \%$. Therefore, even agents of a compromise type are not able to act effectively in the context of a conflict.

Figure 2d) shows the behavior of deviating agents (agent $i$ resource level) and compromise agents (agent $j$ resource level) types. Figure $2 \mathrm{e}$ ) shows the interaction of deviating agents (agent $i$ resource level) and coercive agents (agent $j$ resource level). Figure $2 \mathrm{f}$ ) shows the interaction of compromise agents (agent $i$ resource level) and coercive agents (agent $j$ resource level).

From the presented behavior models in figure 2 the best model is $2 \mathrm{f}$ ).

Table 2 provides the information about which step ends the allocation of resources between agents resulting from the condition (6).

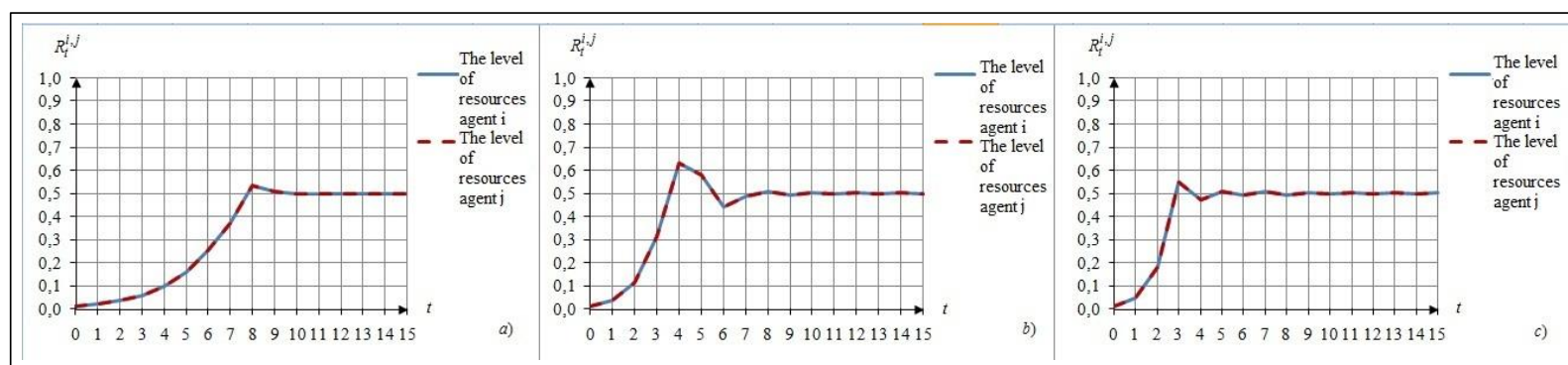

Fig. 1. Distribution curves of same type agents' resource

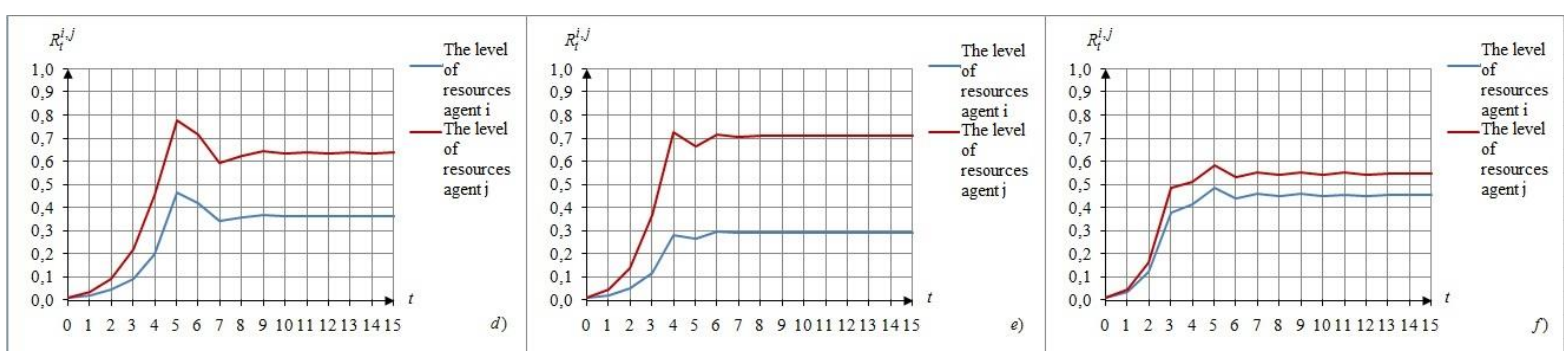

Fig. 2. Distribution curves of resource of different type agents 
The results of time distribution

Table 2

\begin{tabular}{|l|c|c|c|}
\hline Types of agents & Deviating & Compromise & Coercing \\
\hline Deviating & $7 ; 1 \mathrm{a})$ & $4 ; 2 \mathrm{~d})$ & $3 ; 2 \mathrm{e})$ \\
\hline Compromise & $4 ; 2 \mathrm{~d})$ & $3 ; 1 \mathrm{~b})$ & $4 ; 2 \mathrm{f})$ \\
\hline Coercing & $3 ; 2 \mathrm{e})$ & $4 ; 2 \mathrm{f})$ & $2 ; 1 \mathrm{c})$ \\
\hline
\end{tabular}

Table 2 shows that resource allocation time, that most closely matches the specified condition $T=5$, is equal to four iterations. It is typical for models of the interaction "Deviating $\leftrightarrow$ Compromise" (2d)) and "Compromise $\leftrightarrow$ Coercing" (2f)). Thus, we confirm a hypothesis about a constructive side of a conflict: negotiation between agents of different types, one of which is compromise, extend the field of agents' activity; give them the opportunity to negotiate and to come closer to fulfilling these conditions. All other models of interaction are recognized as ineffective. In models 1b), 2e) and 1c) the distribution of resource occurs too quickly and the agents "don't realize" the essence of the task because of confrontation. In the model 1a) the resource is distributed too slowly, so performing tasks by such agents is delayed.

Table 3 shows how much resource is left unallocated at the moment $T$.

Table 3

Unallocated resource in agents' behavioral models of in a conflict

\begin{tabular}{|l|c|c|c|}
\hline Types of agents & Deviating & Compromise & Coercing \\
\hline Deviating & $0,26 ; 1 \mathrm{a})$ & $0,35 ; 2 \mathrm{~d})$ & $0,52 ; 2 \mathrm{e})$ \\
\hline Compromise & $0,35 ; 2 \mathrm{~d})$ & $0,37 ; 1 \mathrm{~b})$ & $0,07 ; 2 \mathrm{f})$ \\
\hline Coercing & $0,52 ; 2 \mathrm{e})$ & $0,07 ; 2 \mathrm{f})$ & $0,64 ; 1 \mathrm{c})$ \\
\hline
\end{tabular}

The best distribution score is obtained in the model $2 \mathrm{f}$ ), since it has only $7 \%$ of unallocated resource on the fifth iteration of the distribution. The remaining values show that agents need to change their strategy of behavior, otherwise they will experience a significant resource shortage that will not allow them to complete the task in the allotted time. Although the model 2f) is the most effective among all presented models, it is also not perfect.

To change the strategy of agents' behavior and minimize a conflict we can use the following activities:

- if possible, to ensure reserve replenishment;

- assisting agents from the outside, for example, providing opportunities for other agents to share their resources with the considered agents;

- selecting agents that can effectively express themselves working in pairs despite the possibility of conflict between them.

For example, under the same conditions assisting the $i$-th agent only in the first iteration as $\varepsilon_{1}^{i}=0,01$ (fig. 3a) allows a full distribution of the resource (100\%), but for 8 iterations.

Now 3d) model is the best, when the assistance is provided for a deviating agent. The assistance for a compromise-type agent in model $3 \mathrm{f}$ ) causes negative emotions from a coercing-type agent, which only worsens a conflict.

Further numerical experiments showed that it is important to be attentive to the initial distribution of resources between agents and before assisting any of them to analyze the need for this. It is possible that the result will be like: "We wished our best, you know the rest!"

Additionally, we analyze the dependence of agents' "fatigue" from their psycho-behavioral type, i.e. we check the fulfillment of the condition (8):

$$
\lambda_{t}^{i} \lambda_{t}^{j}>\eta_{t}^{i} \eta_{t}^{j}
$$

where $\lambda_{t}^{i} \lambda_{t}^{j}$ is an assessment of agents" "fatigue" from conflict; $\eta_{t}^{i} \eta_{t}^{j}$ is evaluation of agents' reaction to the actions of each other.

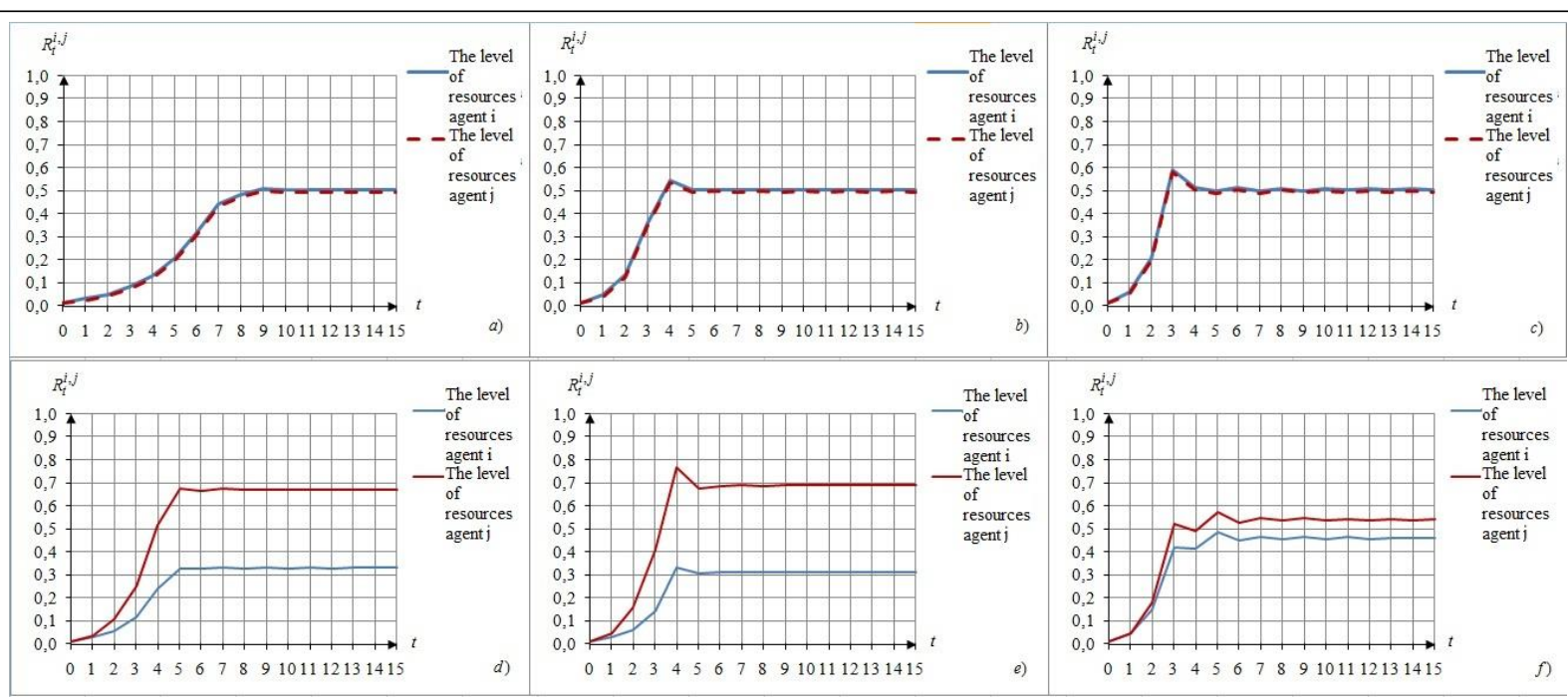

Fig. 3. Changes in agents' behavior when providing a one-time assistance to the $i$-th agent 


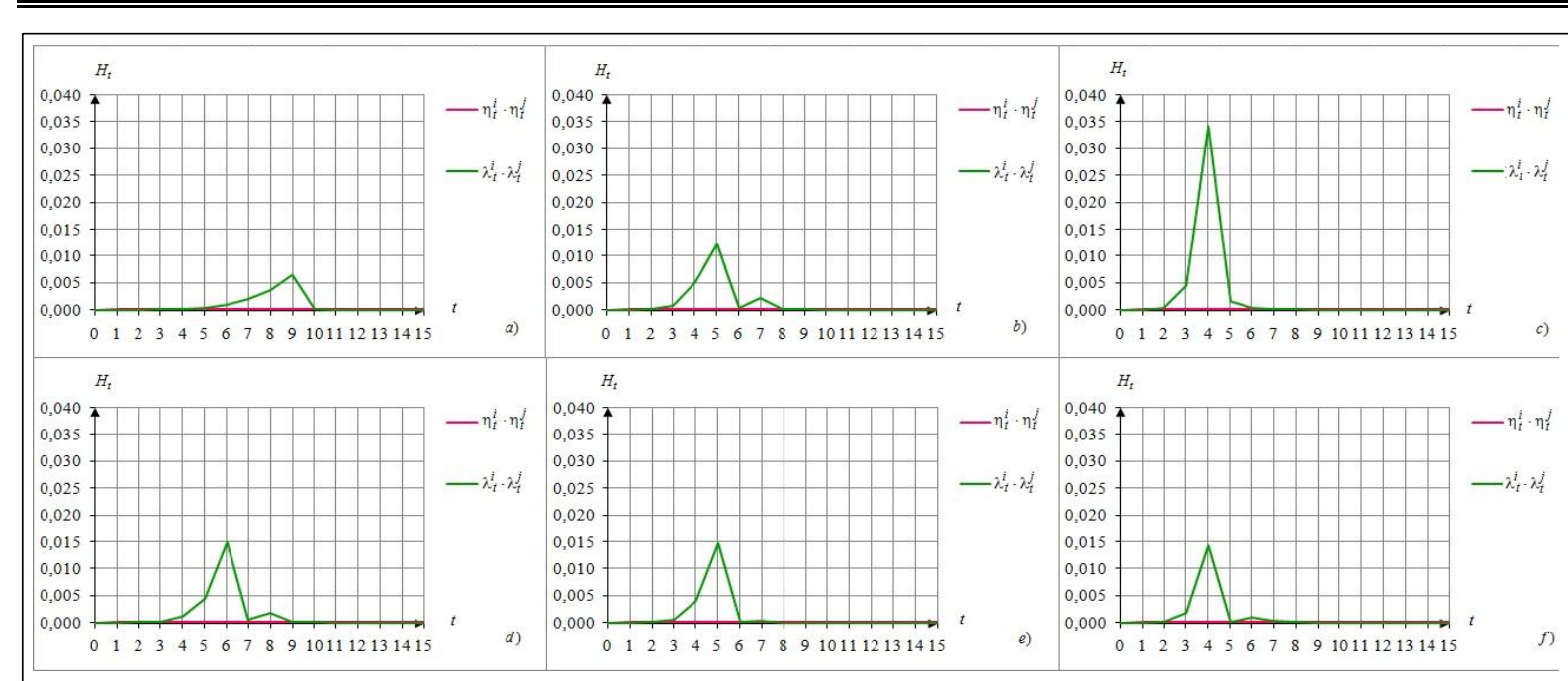

Fig. 4. The dependence of agents' "fatigue" on their type when interacting in conflict

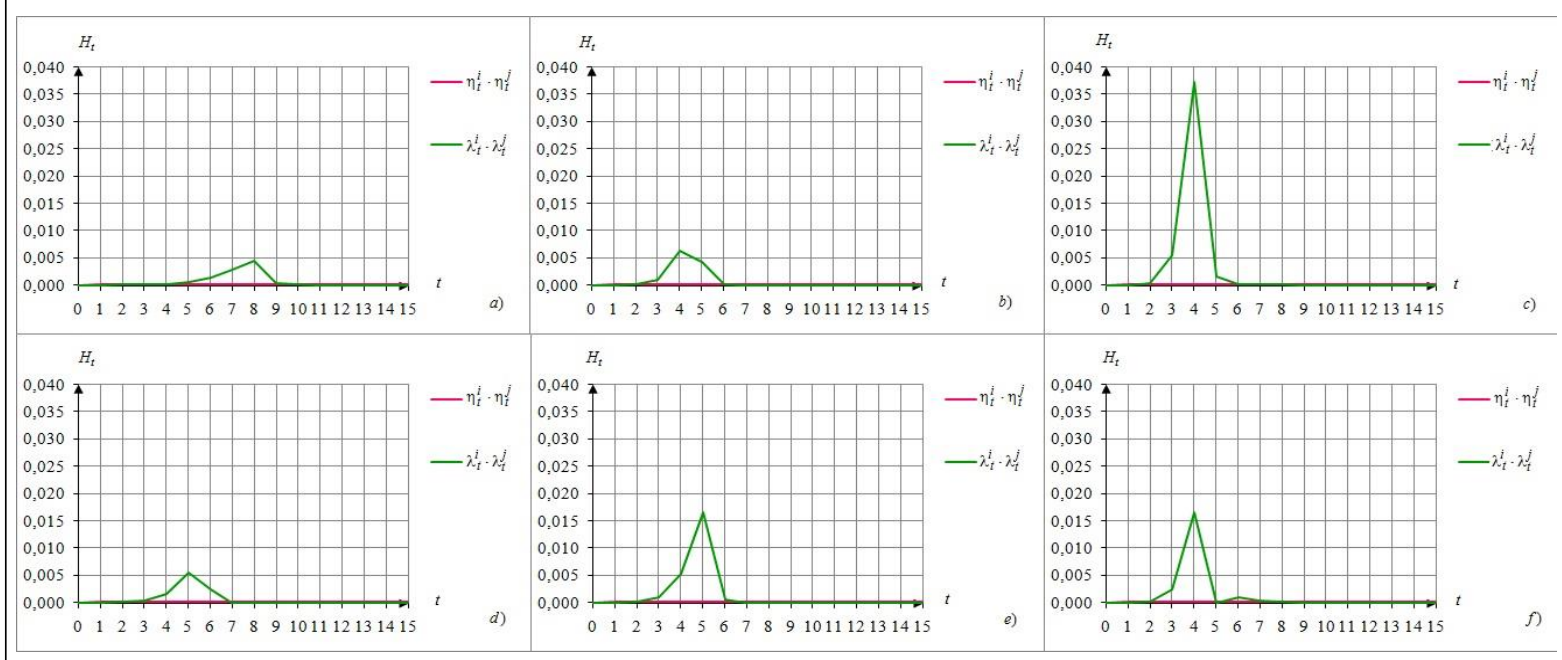

Fig. 5. The dependence of agents' "fatigue" on their type when providing assistance to the $i$-th agent

The period of operation of the following inequality (8) shows the active phase of the conflict. In figure 4 shows the active phases of the conflict between agents in all considered models.

The graphs in figure 4 correspond to agents' behavior during sharing of resources presented in figure 1 and figure 2 . It is obvious that coercing agents experience the greatest "fatigue" (fig. 4c), and deviating agents experience the lowest "fatigue" (fig. 4a). Other behavioral models are characterized by negotiation, so the peak of "fatigue" is about on the same level.

Figure 3 presents the models with little changes in the graphs of this dependence (fig. 5).

Now we can see the least "fatigue" in models a) and d). Based on the simulation results above, when assisting the deviating agent in the amount of $1 \%$ on the first iteration, the model d) is recognized as the best.

\section{Conclusion}

Since this study considers an agent as an intelligent anthropomorphic entity characterized by mental prop- erties, the description of pair models of agents' behavior in conflict is based on the hypothesis of the implementation of agents behavior proposed by American scientists K. Thomas and R. Kilmann [9, 10]. They identified five main styles of behavior in a conflict situation: adaptation (pliability), deviation, competition (rivalry), cooperation and compromise. Thus, classification features are: the degree of implementation of agent's own interests and achieving their goals; the degree in which they consider the interests of the opponent. Deviation and pliability strategies are peculiar to deviating agents. Compromise agents can follow the adaptation strategy, as well as and the compromise strategy. Coercing agents typically choose the strategy of confrontation. The simulation results show that both agents can win with only one strategy. It is cooperation.

Acknowledgements. The research was supported by the RFBR, project no. 15-01-05545- $a$.

\section{References}

1. Mutovkina N.Yu., Kuznetsov V.N., Klyushin A.Yu. The influence of goal-seeking behavior of agents on multi-agent system 
stability. Sistemy upravleniya $i$ informatsionnye tekhnologii [Systems of Control and Information Technologies]. 2014, no. 2 (56), pp. 43-48 (in Russ.).

2. Mutovkina N.Yu., Klyushin A.Yu., Kuznetsov V.N. Methods of harmonized management of conflict in a multi-agent system. Sistemy upravleniya i informatsionnye tekhnologii [Systems of Control and Information Technologies]. 2014, no. 3.2 (57), pp. 255-261 (in Russ.)

3. Klyushin A.Yu., Kuznetsov V.N., Mutovkina N.Yu. The fuzzy models of the behavior of individuals and groups making decisions. Tver, TvSTU Publ., 2015, part 2, 248 p. (in Russ.).

4. Fisher R., Ury W. Getting to Yes: Negotiating agreement without giving in. Penguin Group Publ., UK, 1981, 200 p.

5. Mutovkina N.Yu., Klyushin A.Yu., Kuznetsov V.N Semantic definition of the agent type in a multi-agent system. The problem of interaction between agents. Open Semantic Technologies for Intelligent Systems (OSTIS-2013). Proc. 3rd Int. Sc. Conf.
(Golenkov V.V., ed.). Minsk, BGUIR Publ., 2013, pp. 309-316 (in Russ.).

6. Antsupov A. Konfliktologiya [Conflictology]. SPb, Piter, 2013, 304 p. (in Russ.).

7. Desyatov D.B. The conflict theory. Voronezh, Sc. Book Publ., 2008, 346 p. (in Russ.)

8. Ponomarev Yu.P. Game models. Mathematical methods. Psychological analysis. Moscow, Nauka, 1991, 160 p. (in Russ.)

9. Kilmann R.H., Thomas K.W. Interpersonal conflicthandling behavior as reflections of Jungian personality dimensions. Psychological Reports. 1975, vol. 37, no. 3, pp. 971-980. Available at: www.kilmanndiagnostics.com (accessed August 9, 2015).

10. Kilmann R.H., Thomas K.W. Developing a forced-choice measure of conflict-handling behavior: The "mode" instrument. Educational and Psychological Measurement. 1977, vol. 37, no. 2, pp. 309-325. Available at: www.kilmanndiagnostics.com (accessed August 9, 2015).

\section{МОДЕЛИ ПОВЕДЕНИЯ РАЗНОТИПНЫХ АГЕНТОВ В УСЛОВИЯХ КОНФЛИКТА И АЛГОРИТМЫ ИХ РЕАЛИЗАЦИИ}

Н.Ю. Мутовкина, к.т.н., доцент, letter-boxnm@ya.ru;

А.Ю. Клюшин, к.т.н., доиент, klalex@inbox.ru;

Н.А. Семенов, д.т.н., профессор, is@tstu.tver.ru

(Тверской государственньй технический университет, наб. Аф. Никитина, 22, г. Тверь, 170026, Россия)

В статье рассматриваются парные модели поведения агентов в условиях конфликта, каждый из которых обладает одним из трех возможных поведенческих типов: уклоняющийся, компромиссный и принуждающий. Поведенческий тип определяет характер агента и указывает, какой реакции от агента следует ожидать в ответ на конкретные действия. В качестве основной причины конфликта при моделировании выбрана необходимость делить ограниченный объем ресурсов. Ресурсы необходимы для выполнения агентами поставленных задач и самого существования агентов. Установлено, что в ситуации конфликта каждый агент стремится получить большее количество ресурсов, чем есть в данный момент у соперника. Величина этого стремления зависит от поведенческого типа агента. В работе определена методика выбора лучшей модели поведения, а также предложены мероприятия по устранению конфликтной ситуации между агентами. При моделировании были применены основные постулаты нечеткой логики.

Ключевые слова: межагентный конфликт, поведенческий тип, нечеткая логика, модель поведения, уровень ресурсной обеспеченности.

Работа выполнена при поддержке РФФИ, грант № 15-01-05545-а.

\section{Лuтература}

1. Мутовкина Н.Ю., Кузнецов В.Н., Клюшин А.Ю. Влияние целеустремленного поведения агентов на устойчивость многоагентной системы // Системы управления и информационные технологии. 2014. № 2 (56). С. 43-48.

2. Мутовкина Н.Ю., Кузнецов В.Н., Клюшин А.Ю. Методы согласованного управления конфликтом в многоагентной системе // Системы управления и информационные технологии. 2014. № 3.2 (57). С. 255-261.

3. Клюшин А.Ю., Кузнецов В.Н., Мутовкина Н.Ю. Нечеткие модели поведения лиц и групп, принимающих решения: монография. Ч. 2. Тверь: Изд-во ТГТУ, 2015. 248 с.

4. Фишер Р., Юри У. Путь к согласию, или Переговоры без поражения; [пер. с англ.]. М.: Наука, 1990. 160 с.

5. Мутовкина Н.Ю., Клюшин А.Ю., Кузнецов В.Н. Семантическое определение типа агента в многоагентной системе. Проблема межагентного взаимодействия // Открытые семантические технологии проектирования интеллектуальных систем = Open Semantic Technologies for Intelligent Systems (OSTIS-2013): матер. III Междунар. науч.-технич. конф. Минск: Изд-во БГУИР, 2013. С. 309-316.

6. Анцупов А. Конфликтология. СПб: Питер, 2013. 304 с.

7. Десятов Д.Б. Теория конфликта: монография. Воронеж: Научная книга, 2008. 346 с.

8. Пономарев Ю.П. Игровые модели. Математические методы. Психологический анализ. М.: Наука, 1991.160 с.

9. Kilmann R.H., Thomas K.W. Interpersonal Conflict-Handling Behavior as Reflections of Jungian Personality Dimensions. Psychological Reports. 1975, vol. 37, no. 3, pp. 971-980. URL: www.kilmanndiagnostics.com (дата обращения: 9.08.2015).

10. Kilmann R.H., Thomas K.W. Developing a Forced-Choice Measure of Conflict-Handling Behavior: The "Mode" Instrument. Educational and Psychological Measurement. 1977, vol. 37, no. 2, pp. 309-325. URL: www.kilmanndiagnostics. com (дата обращения: 9.08.2015). 